\title{
Research on Key Technologies of Solar Photovoltaic Building Integration
}

\author{
Yan Li*, Jianfeng Zhang, Yinghao Gan \\ East University of Heilongjiang, Harbin 150066, Heilongjiang Province, China \\ *Corresponding author: Yan Li, 355958909@qq.com
}

\begin{abstract}
On December 21, 2020, The State Council Information Office issued a white paper titled "China's Energy Development in the New Era," in which the installed capacity of hydropower, wind power, photovoltaic power and biomass power generation in China ranked first in the world ${ }^{[1]}$. Solar photovoltaic power generation is the most important development direction of clean energy in the world. It is an important energy strategy to combine it with the field of construction in China. This paper mainly introduces the characteristics and problems of the key technologies of solar photovoltaic building integration, and explores its future development direction and ways, in order to constantly promote the industrialization of new energy technology in China.
\end{abstract}

Keywords: Solar photovoltaic building; Clean energy; Integration; Key technologies

Publication date: July 2021; Online publication: July 31, 2021

\section{Introduction}

As the name suggests, the key technology of solar photovoltaic building integration is to organically combine solar photovoltaic power generation and buildings. The combination here is not a simple addition of functions, but to reflect the idea of "building energy production." The most common practice is to build photovoltaic power generation equipment on the exterior structure of the building construction in time to improve the design sense of the building while providing it with additional power energy, so that the building and photovoltaic power generation technology form a unified whole, and the two complement each other. Since 2009, China has issued a series of important documents to promote the development of photovoltaic power generation projects, represented by the Implementation Opinions on Accelerating the Application of Solar Photovoltaic Buildings ${ }^{[2]}$. Since then, the research on the integration of solar photovoltaic buildings has developed rapidly. It has become a key research topic of renewable energy development and utilization in China.

\section{The characteristics of the key technologies of solar photovoltaic building integration}

2.1. The integration of solar photovoltaic buildings can realize the rational utilization of resources The use of solar photovoltaic building integration key technology can effectively utilize the external structure of the building while using solar photovoltaic power generation, such as directly laying photovoltaic power generation equipment on the roof or wall. It does not occupy land resources other than the building itself, nor does it need to build other power generation facilities. Especially for the first-tier and second-tier cities, the population is becoming more and more dense, making land resources become scarce and expensive. In this case, the integrated design of solar photovoltaic building integration can give full play to the function of photovoltaic power generation and maximize the rational utilization of resources. At the same time, the solar photovoltaic power generation function can provide additional power demand 
on the basis of the internal electricity of the building, especially in the hot summer, or when large factory buildings need to run air-conditioning, refrigeration equipment or large machinery and equipment, which can fully meet the power demand of the building. While alleviating the power supply pressure during the peak period of construction, it can solve the summer power load, or temporarily increase the power consumption of more resources, and provide sustainable and stable power supply for the building, so as to maximize the resource efficiency and economic benefits.

\subsection{The integration of solar photovoltaic buildings can reduce the cost}

The key technology of solar photovoltaic building integration can reduce the cost of additional electricity equipment in building construction, and the cost of solar photovoltaic power generation is lower than that of grid power supply or grid connection support. It is mainly based on the installation of photovoltaic array power generation equipment, which can fully supplement the power consumption of buildings and reduce the cost of electricity consumption. At the same time, solar photovoltaic array can also serve as a high-rise building shading facility, avoid building external structure caused by high temperature and other problems, improve the indoor temperature with light environment, reduce air conditioning, refrigeration equipment electricity costs, reduce extra shading and cooling facilities installation cost, eliminating the peripheral building maintenance materials of construction, further reduce the cost of construction.

\subsection{Integration of solar photovoltaic buildings can give full play to the economic effects of environmental protection}

As a major power demand country, China's electricity consumption is increasing every year. In 2020, China's electricity supply and demand gap has reached nearly $11 \%$, and the proportion of clean energy generation is not high ${ }^{[3]}$. As human beings become more active on the earth, the adverse impact on the environment is becoming more serious. The key technologies of solar photovoltaic building integration use solar energy for photovoltaic power generation. Solar energy is inexhaustible compared with other power sources such as coal, oil and water power. Additionally, the use of solar power generation, will not produce thermal power generation, fossil fuel power generation caused by air pollution, solid pollution, can reduce the air emissions of various greenhouse gases, so as to alleviate the urban greenhouse effect. At the same time, solar energy belongs to clean energy, which can produce better environmental and economic effects, and embodies the concept of green and sustainable development.

\section{The key technology of solar photovoltaic building integration is insufficient}

\subsection{The key technology of solar photovoltaic building integration is not mature}

With the introduction of the national policy of supporting the research on key technologies of solar photovoltaic building integration, the research process of solar photovoltaic building integration in China has been gradually accelerated in recent years. However, China has joined the field of solar photovoltaic building for a short time, and the research on key technologies is still not mature enough. First, there is no unified and recognized system for the technical standards and specifications of the integrated construction of solar photovoltaic buildings. Research on photovoltaic building technology is relatively scattered, and most of the funding is supported by government subsidies. As an emerging technology, the research intensity and depth of the key technology of solar photovoltaic building integration in China are not as strong as those of western countries represented by Germany. Therefore, there are not many building cases that truly realize the integration of photovoltaic buildings in recent years. Second, the construction of solar photovoltaic building integration needs not only the maturity of photovoltaic power generation technology, but also the organic combination of photovoltaic power generation and architectural design and the production of related accessories. Additionally, it can produce photovoltaic array component of domestic 
enterprises is not much, and the technical level is not high, especially solar photovoltaic building integrated involving curtain wall, outer shading building materials design, installation and other technical requirements, the related demand of domestic can realize company is relatively small, still need to be imported from abroad for key technology. Therefore, the development of the key technology of solar photovoltaic building integration is not only an issue of its own technical level, but also requires considerable progress in architectural design, component quality, process and structure to promote the rapid development of photovoltaic building integration technology in an all-round way ${ }^{[4]}$.

\subsection{At present, the power generation efficiency of photovoltaic cells in China is low}

At present, solar photovoltaic power generation in China is mainly carried out by using battery modules. Domestic commonly used battery modules include monocrystalline silicon, polysilicon, amorphous silicon film, copper indium gallium selenium and so on. In comparison, the most widely used and widely accepted battery components are crystalline silicon. Crystalline silicon can be divided into monocrystalline silicon and polycrystalline silicon, both on the sun light is very high, pervious to light quality is not strong, crystalline silicon itself if hair form a complete set of solar photovoltaic components of light transmittance is also not strong, and photovoltaic building integrated design, the shading rate factor comprehensive enough, will significantly affect the efficiency of the crystalline silicon. However, because the crystalline silicon battery has been applied in China for a long time, the technology has been relatively mature, and the power generation is stable, the market is still the most recognized.

In contrast, amorphous silicon thin film cells, which are relatively new in recent years, are cheaper to build than crystalline silicon cells and are smaller and easier to assemble and use. However, the technology of amorphous film is relatively complex, and few companies can master it, which cannot form a wide range of promotion and use. Moreover, heavy metal pollution is easy to occur in the production process, which does not meet the green environmental protection and energy saving requirements in the field of solar photovoltaic building integration. Moreover, the power generation of amorphous silicon thin film cells is not as stable as that of crystalline silicon cells, and its application technology still needs further development and research. Therefore, in general, the power generation rate of domestic solar photovoltaic cells cannot meet the development needs of photovoltaic building integration.

\subsection{High requirements for integrated design of photovoltaic buildings}

If you want to carry out the integrated construction of photovoltaic buildings, you should carry out the overall construction design from the beginning, and take full account of the appearance and internal functionality and other comprehensive factors. For example, whether the size and color of solar photovoltaic power generation modules are coordinated with the building itself, whether it affects the beauty of the building; Whether the installation position can give full play to the function of its components to convert solar energy into electric energy, and whether the function of shading and modification can be realized. At the same time, it should not affect the load-bearing, windproof, waterproof and other functions of the building. Especially in the current market, the buildings that can use the integrated construction of solar photovoltaic buildings are generally high-rise buildings in cities, with more light time and greater power demand ${ }^{[5]}$. This puts forward strict requirements on the pipeline safety of the integrated design of photovoltaic buildings, and the ability of the battery components to withstand rain, snow, hail and wind. But also facilitate future maintenance, repair, replacement and system maintenance and upgrade. In general, it is on the basis of giving full play to the role of solar photovoltaic power generation and forming an organic combination with the function, beauty and overall style of the building. 


\section{The development trend of key technologies of solar photovoltaic building integration \\ 4.1. Gradually replace thermal power, fossil and other traditional energy sources for power generation}

At present, the international on the disadvantages of traditional energy sources such as coal and fossil power generation has a very profound understanding, in addition to the consumption of non-renewable resources, its produce all kinds of pollution has seriously affected the normal life of mankind, as a result, the clean energy such as solar power generation technology, will become the development trend of energy in the future, especially with the deepening of the research. With the maturity of technology, the use of green energy such as solar photovoltaic building integration will gradually replace the traditional energy generation.

\subsection{The trend of large-scale application}

At present, the application scope of domestic solar photovoltaic building integration is not wide, and the market acceptance is not high enough. However, the advantages of the key technology of photovoltaic building integration are obvious. With the deepening of research, the shortcomings and disadvantages will be gradually overcome and reduced. The key technology of solar photovoltaic building integration will be promoted and applied in the market on a large scale to promote the development of China's new energy technology.

\section{Acknowledgments}

University-level Scientific Research Project of East University of Heilongjiang (Project No. HDFKY210106)

\section{Disclosure statement}

The author declares no conflict of interest.

\section{References}

[1] Zhou J, Zhao J, Liu C, 2012, Energy Consumption Evaluation of Solar Photovoltaic Buildings based on the Whole Life Cycle. Building Thermal Energy, Ventilation and Air conditioning, (06).

[2] Yang Z, Liu J, 2011, Research on Technology Track Identification based on Patent Citation Network -- A Case Study of Solar Photovoltaic Panel Field. Studies in Science of Science, 29(9):1311-1317.

[3] Liu W. Zhao Y, 2012, Integrated Construction of Large Area Non-Silicon Solar Photovoltaic Power Generation Roof System and Building. Science \& Technology \& Life, (20).

[4] Zhang X, 2005, Application of Solar Photovoltaic Panels in Building Integration. Architecture, (2):80-83.

[5] Wang S, Wu D, 2016, Solar Energy, (6):19-24. 